\title{
Vahid Behmardi. Rhetorical Values in Buyid Persia According to Badi' al-Zaman al-Hamadhani
}

\section{Colin P. Mitchell}

\section{(2) OpenEdition}

1 Journals

\section{Édition électronique}

URL : http://journals.openedition.org/abstractairanica/40943

DOI : 10.4000/abstractairanica.40943

ISSN : 1961-960X

Éditeur:

CNRS (UMR 7528 Mondes iraniens et indiens), Éditions de l'IFRI

\section{Édition imprimée}

Date de publication : 1 décembre 2013

ISSN : 0240-8910

\section{Référence électronique}

Colin P. Mitchell, « Vahid Behmardi. Rhetorical Values in Buyid Persia According to Badi' al-Zaman alHamadhani », Abstracta Iranica [En ligne], Volume 32-33 | 2013, document 418, mis en ligne le 01 juillet 2016, consulté le 03 octobre 2020. URL : http://journals.openedition.org/abstractairanica/40943 ; DOI : https://doi.org/10.4000/abstractairanica.40943

Ce document a été généré automatiquement le 3 octobre 2020.

Tous droits réservés 


\title{
Vahid Behmardi. Rhetorical Values in Buyid Persia According to Badi' al-Zaman al-Hamadhani
}

\author{
Colin P. Mitchell
}

\section{RÉFÉRENCE}

Vahid Behmardi. « Rhetorical Values in Buyid Persia According to Badi' al-Zaman alHamadhani ». in : Lale Behzadi, Vahid Behmardi, eds., The Weaving of Words: Approaches to Classical Arabic Prose. Beirut, Orient Institut Beirut, 2009, p. 151-164. (Beiruter Texte und Studien, 112)

1 Vahīd Behmardī examines herein the degree to which Iranian litterateurs influenced and shaped the nature of Arabic prose during the Buyid period. Focusing principally on the Maqāmat of Badī‘ al-Zamān al-Hamadānī, but also drawing on other Iranian authors writing in Arabic, Behmardī argues that rhetoric and epistolography made a florid use of literary techniques during the Buyid period. He makes the case that Iranian prose authors were attracted by the literary potential of the rhetorical sciences, as opposed to the Qur'an-defined rules of rhetoric established by 'Abd al-Qāher al-Jorjānī. A new "craft" (sañ̄'at) was shaped that spoke to their tastes for stylized language and literary techniques, such as similes, metaphors and antitheses. 


\section{AUTEURS}

COLIN P. MITCHELL

Dalhousie University, Canada 